УДК 65.012 .34

DOI 10.15673/fie.v13i4.2191

Ніколюк О.В.

доктор економічних наук, профессор кафедра публічного управління

та адміністрування

Email: alenavn11@gmail.com ORCID ID: 0000-0002-1665-0361

\author{
Соколюк К.Ю. \\ кандидат економічних наук, доцент \\ кафредра маркетингу, підприємництва і торгівлі \\ E-mail: katya.sokoluk@meta.ua \\ ORCID ID: 0000-0002-0758-6468
}

\author{
Димбовська Л.І. \\ магістрант \\ кафедри менеджменту і логістики \\ Одеська національна академія харчових технологій \\ вул. Канатна 112, м. Одеса, Україна, 65039 \\ E-mail: Id270399@gmail.com \\ ORCID ID: 0000-0003-3809-4973
}

\title{
ЛОГІСТИКА ФУНКЦІОНАЛЬНИХ ОБЛАСТЕЙ: ТЕОРЕТИЧНІ ПІДХОДИ
}

У статті сформульовано універсальні теоретико-методологічні засади логістичного підходу, який використовується для вирішення різних завдань стратегічного управління підприємствами. Запропоновано засади теорії кадрової логістики, насамперед концептуальні й науково-методичні положення щодо забезпечення організації і підвищення результативності використання персоналу підприємств на відповідних методологічних засадах імплементації логістичного підходу. Визначено, що логістичний підхід є важливою складовою у забезпеченні адаптивності підприємств до зовнішнього середовища. Встановлено, що формування логістичних систем в комерції передбачає інтеграцію систем руху товарно-матеріальних потоків на основі координації всіх процесів товаропросування, починаючи від закупівель товарів і закінчуючи поставкою їх споживачам, інтеграції управління товарними потоками, єдиної технології матеріального потоку, разом із комплексом послуг, що надаються клієнтам торговельного підприємства, адаптації логістичних систем до зміни зовнішнього та внутрішнього середовища комерційної логістики, раціональної організації всіх елементів комерційної логістики, забезпечення їх сумісності в організаційному і технологічному плані та інше.

Ключові слова: логістика, управління, підприємства, кадри, система управління, логістичні підходи, механізми.

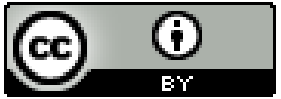

This work is licensed under a Creative Commons Attribution 4.0 International License http://creativecommons.org/licenses/by/4.0/
Постановка проблеми та її зв'язок з важливими науковими та практичними завданнями. Для забезпечення реалізації стратегії сталого розвитку національної економіки доцільно, щоб трансформація на рівні суб'єктів господарювання зазвичай поєднувалась із адекватною політикою від органів державної й місцевої влади. Дієва економічна політика може також бути результативною лише тоді, коли вектор змін безпосередньо співпадає на всіх представлених рівнях управління підприємствами. Враховуючи це актуальною є розроблена наукова проблема щодо теоретико-прикладних положень розробки й підтримки логістичних механізмів для адаптації підприємств до різних мінливих зовнішніх впливів. Їі вирішення насамперед дозволить підвищити рівень конкурентоспроможності підприємств й гармонізувати соціально-економічні інтереси різних суб'єктів ринкових відносин.

Перспективність проведення дослідження із різних фундаментальних теоретичних й науково- прикладних питань логістики безпосередньо викликана вимогою щодо підготовки рекомендацій, які дозволятимуть стимулювати реформи на мікроекономічному рівні. Безпосереднє використання інструментів логістики також дозволить покращити їх внутрішнє середовище й сформувати належне зовнішнє середовищє господарювання підприємства. Загалом формування логістичної системи насамперед призначено для підвищення рівня конкурентоспроможності підприємства. Тобто, логістика повинна стати важливим ринковим інструментом для підприємств.

Аналіз останніх публікацій по проблемі. Різні аспекти логістики як ключового важеля розвитку підприємств досліджували вітчизняні науковці О. Амоша, А. Войчак, С. Гаркавенко, В. Герасимчук, Я. Дроботя, В. Заруба, А. Кальченко, С. Крикавський, О. Кузьмін, П. Орлов, А. Павленко В. Пилипчук, І. Савенко, Н. Тюріна, Д. Штефанич та ін.

Формулювання цілей дослідження. Мета 
статті полягає в обгрунтуванні концептуальнометодологічних положень формування і підтримки розвитку логістичних систем підприємств як наукового підгрунтя для покращення результатів господарської діяльності.

Виклад основних результатів та їх обгрунтування. На сьогодні кадрова політика стає важелем виключно локальним. Тому необхідно безпосередньо привести у відповідність до сучасних реалій стратегію, діючу тактику, організаційну структуру, існуючий зміст діяльності для кадрових підрозділів. Варто розробити дієвий організаційно-управлінський механізм щодо активізації важливого трудоресурсного фактору, ідентифікувати критерій й створити практичну методику розрахунку індикатора ефективності щодо його функціонування.

3 метою досягнення бажаного результату представлений кадровий менеджмент варто проводити керуючись практичною концепцією й методологією логістики. Врегулювання проблеми також можливе на основі використання спеціального організаційно-управлінського механізму - дієвої системи управління кадрами. Таким чином за ії допомогою $\epsilon$ можливою нейтралізація появу частини оптимізації певних компонентів для кадрової роботи, що може призвести до ризиків в діяльності системи управління певним підприємством.

Концепція та методологія логістики на етапі використання в кадровому управлінні може бути також інтерпретована у такому вигляді. Управління кадровим потенціалом підприємства - це метод забезпечення підвищення соціально-економічної результативності використання трудових ресурсів на основі інтерпретації організаційно-управлінського механізму щодо координації існуючих кадрових функцій (динамічної системи управління кадровими ресурсами). Метою такого управління на підприємстві $\epsilon$ оптимізація соціально-економічної ефективності щодо їх використання. Зміст управління трудовими ресурсами для підприємства полягає насамперед в тому, щоб реалізувати відповідні системи, отримувати позитивний додатковий ефект на основі раціональної взаємодії існуючих кадрових функцій. Такий синергетичний ефект забезпечує отримання поставленої цілі. Зміст системи управління трудовими ресурсами для підприємства складає злагоджену сукупність семи основних кадрових функцій: збір, підготовка, розстановка, процес перепідготовки, професійно-кваліфікаційне зростання для кадрів, оплата й стимулювання праці.

В умовах стрімкого розвитку інформаційного суспільства інформація постійно стає робочим агентом для економічної діяльності, активізуючи й регулюючи відповідні їі механізми. Завдання щодо управління інформаційними ресурсами також набуває пріоритетного значення у інформаційній економіці. Таким чином інформаційна логістика є одним із ключових інструментів, які покликані врегулювати дане завдання.

Інформаційна логістика розглядається як системний комплекс стратегічних заходів, які орієнто- вані насамперед на управління виробництвом інформації, іiі безпосереднім рухом й збутом із визначеними мінімальними витратами. Таким чином інформаційна логістика є своєрідним простором для «звичайної» логістики, тоді остання входить до даного простору, адаптуючись певним чином у ньому [1-2].

Ефективне інформаційно-аналітичне забезпечення є базисом для процесів визначення й прийняття науково визначених управлінських рішень. Таке дієве забезпечення має враховувати сучасні інформаційні технології, методи аналізу-синтезу існуючої інформації, певній системі науково-технологічної й економічної інформації. Динамічний розвиток існуючих інформаційних й телекомунікаційних технологій $€$ актуальною тенденцією для світової економіки. Діючі інформаційні комунікації належним чином стануть одним із головних ресурсів розвитку у XXI столітті. Імплементація інформаційних технологій у різні сфери економіки спроможне кардинально змінити діючі механізми функціонування більшості інститутів суспільства, насамперед, й самої держави. В сучасних умовах відбувається поступове просування до інформаційної економіки, тому формування й розповсюдження інформації $є$ фундаментом діяльності підприємств.

Таким чином підприємства постіндустріального типу адаптивні, динамічно розвиваються й потребують для забезпечення стійкості розвитку значно менше звичайних факторів виробництва. Для індустріальної економіки характерні великі підприємства iз малорухомою структурою. Їх потужність представляється величиною капіталу, якиц контролюється. Навпаки, для розвитку постіндустріальної економіки глобальними стають проблеми щодо професіоналізму, а не абсолютної кількості працівників. Таким чином кваліфікація персоналу є головним фактором для інформаційної економіки. Головним фактором забезпечення й зростання конкурентоспроможності економіки також стала, насамперед, спроможність постійно генерувати й ефективно використовувати різні інформаційні технології [3].

Таким чином пропонуємо під інтернетлогістикою розуміти діяльність по управлінню інформаційними потоками, яка здійснюється на основі сучасних Інтернет-технологій. Також вона суттєво збільшує потенціал для підприємств на основі:

- зростання споживацької аудиторії та, як результат, збільшення потенційної місткості для ринку;

- покращення сервісу;

- мінімізація і здешевлення процедур для пошуку контрагентів; розподілу;

- формування нового каналу комунікацій й

- перспективності отримання необхідної інформації та здійснення електронної комерції [4].

Споживачі отримують перспективну можливість вибирати надійного постачальника незалежно від практичного його географічного положення. Таким чином використання е-комерції дає песрпективну можливість вести бізнес на засадах, коли розми- 
ваються практичні кордони й відбувається зближення існуючих технологій й інформаційних засобів. На етапі глобалізації світової економіки такі технології дозволяють бути актуально представленими на всьому глобальному ринку. Різновекторні об'єднання підприємств відбуваються за допомогою використання цифрових технологій для поступового зростання ефективності й розширення ринків, цим самим оминаючи багаточисельних посередників й наближаючись до безпосередніх споживачів. Даний підхід оптимізує господарські процеси й підвищує конкурентоспроможність. Така форма здійснення визначених ділових контактів має також кілька сфер використання.

Таким чином між різними видами бізнесу, така, сфера В2В (business-to-business) $є$ категорією електронної комерції, в умовах коли компанії проводять діяльність, починаючи від практичного вибору постачальника, динамічного процесу замовлення товарів, сприяння отримання рахунків-фактур до безпосереднього проведення платежів й інших операцій на засадах використання електронної комерції [5].

Таким чином між бізнесом й споживачем або B2C (business-to-consumer) представлена категорія електронної комерції, яка $є$ еквівалентом роздрібної торгівлі й представлена різними видами для електронних магазинів із повною пропозицією різних споживчих товарів.

Таким чином між споживачами або С2C (consumer-to-consumer).

Тоді між бізнесом й державними органами B2A/B2G (business-to- administration/government) це категорія електронної комерції, яка включає різні види відносин між існуючими компаніями й державними організаціями. На даний момент такий вид електронної комерції перебуває на етапі формування, однак має перспективи щодо швидкого розвитку за визначеними напрямками як процесу відшкодування податків, сплата різних корпоративних податкових платежів та інше.

Отже, між державою й споживачами - A2C або G2C (administration/government-to-consumer). Caме дана категорія існує лише теоретично, їі поступове зростання пов'язують із різного роду проведеним соціальними виплатами.

Тоді як у рамках окремого бізнесу або Intrabusiness, зазвичай представляється як електронна комерція щодо купівлі і продажу інформації, товарів або послуг через Інтернет, однак також використовуєтьс для безпосередньої передачі інформації у організації через Інтранет, з метою покращення процесів прийняття рішень й нейтралізації дублювання на різних іiї етапах формування.

Таким чином логістичне управління відбувається із іï логістичного центру, який також зв'язаний мережею із об'єктами управління й зовнішнім середовишем. Прийняті логістичні рішення, які приймаються таким центром групуються на два такі види:

1) оперативні, які приймаються i здійснюються в реальному масштабі часу або спря- мовані на безпосередню підтримку функціонування відповідних інформаційних ресурсів для керованого об'єкту;

2) визначені стратегічні, які приймаються після детального аналітичного опрацювання отриманих повідомлень й орієнтовані на розвиток динамічних інформаційних ресурсів для об'єкту управління, які носять випереджаючий характер [6].

Таким чином, інформаційна логістика як динамічна система оперативного управління певним об'єктом, планові параметри якого також повинні бути точно представлені містить такі елементи:

- підсистему щодо формування планових параметрів об'єкту;

- визначену підсистему для вимірювання фактичних параметрів досліджуваного об'єкту;

- підсистему для зворотнього зв'язку з метою порівняння запланованих й фактичних параметрів об'єкту;

- динамічну підсистему корекції отриманих фактичних параметрів об'єкту дій із урахуванням практичних відхилень;

- підсистему щодо комунікацій й обміну інформації, який пов'язує всі представлені елементи.

Отже, представлена інформаційна логістика це модель управління інформаційним потоком, яка циркулює у логістичній системі, відповідно між логістичною системою й зовнішнім середовищем 3 метою забезпечення оптимізації системи управління матеріальним потоком. Також, засобом, які приводять до руху матеріальні й інформаційні потоки, що викликає безпосередньо появу нової економічної категорії, тобто фінансової логістики [7].

Фінансову логістику запропоновано розглядати як управління фінансовим потоком, яка циркулює у відповідній логістичній системі, безпосередньо між логістичною системою й зовнішнім середовищем 3 метою забезпечення оптимізації системи управління матеріальним, інформаційним, інтелектуальними й іншими потоками. Вона є дієвим засобом, який приводить до руху різні потокові процеси на підприємстві.

Головною метою фінансового обслуговування різних товарних потоків у логістиці є забезпечення їх руху фінансовими ресурсами у необхідних обсягах, у потрібні терміни, з використанням найбільш ефективних джерел фінансування [8]. У самому простому випадку кожному товарному потоку відповідає єдиний фінансовий потік. Наприклад, підприємствопродавець на основі угоди купівлі-продажу поставляє підприємству-покупцю продукцію, переміщення якої i створює товарний потік. Підприємство-покупець, використовуючи певну форму розрахунків, виконує оплату поставки цієї продукції, перераховуючи підприємству-продавцю грошові кошти, які у свою чергу утворюють фінансовий потік.

Товарний та фінансовий потоки мають діаметрально протилежну спрямованність, проте прямолінійсть фінансового потоку можлива лише при умові оплати готівкою. У данному випадку фінансовий потік є вторинним, або залежним по відношенню 
до товарного потоку, сприяючи ефективному проходженню товарно-матеріальних цінностей на усьому шляху слідування від підприємства-продавця до підприємства-покупця.

Різноманітність форм та напрямків розвитку сучасного фінансового ринку, а також специфіка механізму його функціонування обумовлює можливість широкого використання цінних паперів та їх похідних інструментів при фінансовому обслуговуванні руху товарних потоків. Необхідно відмітити, що ефективне використання інструментів фондового ринку, окрім оптимізації фінансових потоків, дозволяє значно покращити результативні показники господарської діяльності як підприємства-продавця, так і підприємства-покупця [8]. У першу чергу, це має відношення до збільшення нетто-прибутку господарюючих суб'єктів шляхом мінімізації податкових платежів. Для їх зниження зараз можуть бути використані як можливості окремих державних цінних паперів, так і можливості випуску та обігу векселів різних емітентів. У фінансовій логістиці, для забезпечення потоку та зменшення податкової бази, можуть бути використані деякі схеми за рахунок інструментів фондового ринку [4].

Фінансова логістика має ряд специфічних

ознак:

- фінансовий потік є вторинним, похідним від матеріального потоку;

- джерело виникнення, обсяг, напрям та час початку руху фінансового потоку обумовлено особливостями договору між продавцем і покупцем відносно умов платежу;

- наявність у логістичному ланцюгу третього суб'єкту — комерційного посередника ускладнює схему руху фінансового потоку;

- використання цінних паперів для оптимізації взаєморозрахунків між продавцем та покупцем товару ускладнює механізм фінансового обслуговування матеріального потоку та підвищує ефективність його використання.

Використання фінансової логістики по оцінкам експертів дозволяє отримати економію від 10 до $30 \%$ суми платежу за постачання товарноматеріальних цінностей.

Значення використання логістики в сфері послуг безперервно зростає, що пояснюється рядом причин:

- розповсюдженням соціальних програм, що приймаються урядами;

- розвитоком індустрії послуг и концентрацією у ній все більшого числа компаній та зайнятого працездатного населення;

- націленністю діяльності багатьох фірм на кінцевого споживача;

- розвитоком концепції загального управління якістю в індустрії послуг.

Значна кількість ланок логістичної системи та логістичних посередників $\epsilon$, по суті, підприємствами, у яких послуги тісно пов'язані з продуктом, що розподіляється, просувається на ринку та продається на різних частинах логістичного ланцюга. До таких ланок відносяться різні транспортні компанії, оптові та роздрібні торговці, компанії-дистриб'ютори та ін. При цьому вартість послуг може значно перевищувати витрати на виробництво продукції.

В процесі розробки процедур управління логістичною системою відповідні менеджери фірм, що виробляють послуги, співставляють логістичні дії у звичайному логістичному ланцюгу управління матеріальними потоками (SC-діï) i y логістичному ланцюгу послуг (SR-діï).

Таке співставлення дозволяє логістичним менеджерам фірм, що виробляють послуги, використовувати ті ж принципи та методичні підходи при управлінні потоками послуг, що і для матеріальних потоків. Проте необхідно враховувати, що процедури замовлень та моніторингу послуг звичайно носять більш комплексний характер, ніж аналогічні процедури матеріального логістичного менеджменту. Це пояснюється низкою їх продуктових характеристик:

- невідчутність послуг - проявляється у складності специфікації послуг сервісної фірми, а також у складності їх оцінки з боку покупця;

- покупець часто приймає безпосередню участь у процесі надання послуг;

- послуги споживаються у значних розмірах у той же час, коли вони надаються;

- покупець ніколи не стає власником у процесі придбання послуг;

- надання послуг — це діяльність (процес) i тому послуги не можуть бути протестовані раніше, ніж покупець за них заплатить;

- надання послуг часто містить систему меньших (субсервісних) дій, причому покупець оцінює усі ці дії. Якість і привабливість послуг залежить від здатності покупця дати загальну, підсумкову оцінку дій по наданню послуги [7-9].

Формування логістичних систем в комерції передбачає інтеграцію систем руху товарноматеріальних потоків. Це потребує:

- координації всіх процесів товаропросування, починаючи від закупівель товарів і закінчуючи поставкою їх споживачам;

- інтеграції управління товарними потоками;

- єдиної технології матеріального потоку, разом із комплексом послуг, що надаються клієнтам торговельного підприємства;

- адаптації логістичних систем до зміни зовнішнього та внутрішнього середовища комерційної логістики;

- раціональної організації всіх елементів комерційної логістики, забезпечення їх сумісності в організаційному і технологічному плані.

- зміцнення матеріально-технічної бази торгівлі;

- перегляду стану господарських зв'язків із закупівлі товарів та формування торговельного асортименту;

- розвитку вітчизняного виробництва товарів народного споживання, державної підтримки національних товаровиробників для підвищення 
їх конкурентоспроможності і забезпечення належної якості продукції;

- узгодження діяльності різних суб'єктів комерційної діяльності (у тому числі роздрібної торгівлі) щодо організації товарних потоків, переходу до застосування принципів логістичної інтеграції.

Здійснення цих заходів та погодження всіх прийнятих рішень $з$ комплексом технологічних операцій та набором засобів технічного забезпечення дозволить створити передумови підвищення конкурентоспроможні торговельних підприємств.

Процес формування зв'язків між підприємствами та закладами середньої спеціальної та вищої освіти доцільно будувати на засадах логістичного підходу. Логістичне розуміння взаємодії економіки і освіти може вбачати в освітньому процесі достатні ознаки потоких процесів з їх орієнтацією в часі, просторі, витратах, кількісно-якісних характеристиках. Водночас порівняно із матеріальними, інформаційними чи фінансовими потоками «освітній потік» має деякі істотні особливості:

- якщо для традиційних логістичних потоків основна складність полягає у необхідності прийняття логістичних рішень довгострокового плану, то потік підготовки кадрів через його велику тривалість ускладнюється ще і таким лагом;

- більш значна факторозалежність процесів підготовки кадрів ускладнює можливість врахування одночасно прояву горизонтальних і вертикальних зв'язків при прийнятті логістичних рішень;

- значний прояв економічних наслідків у випадках «складування в запас» елементів потоку підготовки кадрів, оскільки - це безробітні молоді спеціалісти, випускники шкіл, що не змогли стати студентами, фахівці на роботу яких не існує попиту;
- неістотна вартість місця на противагу чинника часу, тобто рішення чи потрібен певний спеціаліст, який зміг знайти роботу за кордоном необхідно було приймати 5-7 років тому [5-8].

Водночас логістика на певному етапі свого розвитку уже сама формує вимоги до кадрового потенціалу. Якщо на першому етапі логістика виконіє роль підтримки кадрового забезпечення, то на наступному етапі, реагуючи на горизонтальні зв'язки, вона виступає генератором кадрового забезпечення логістичної інфраструктури. Вона зумовлює необхідність у фахівцях відповідного рівня та відповідного напрямку знань.

Висновки та перспективи подалыших досліджень. Універсальність логістики проявляється в тому, що логістичний підхід (методологія логістики) може бути використаний не тільки для вирішення виключно логістичних, але й інших економічних проблем підприємства. Запропоновано теоретичні і науково-прикладні основи теорії кадрової логістики, що можуть сприяти вирішенню актуальної проблеми раціональної організації та підвищення ефективності використання персоналу підприємств. Проявом ідеології логістичного підходу, що носить універсальний характер і спрямований на посилення міжфункціональної координації структурних підрозділів підприємств є чотири взаємопов'язані тенденції: об'єднання локальних функцій підприємства в інтегральні функції, тобто бізнес-процеси; скорочення загальної кількості функцій; структурування організацій на основі інтегральних функцій; оптимізація бізнес-процесів в цілому. Логістичний підхід $є$ важливою складовою у забезпеченні адаптивності підприємств до зовнішнього середовища.

\section{Література}

1. Дроботя Я.А. Управління логістикою матеріальних запасів аграрних підприємств: дис. ... канд. екон. наук: 08.00.04: захист: 30 вересня 2011 р. / Керівник: Перебийніс В. І. Полтава: Полтавська державна аграрна академія, 2011. 292 c. doi: 10.1055/s-0038-1628407

2. Савенко I.I. Логістичний підхід в управлінні потоками зернозберігаючих підприємств. Теоретикоправовий та методологічний аспекти: монографія. Одеська національна академія харчових технологій. Одеса: Поліграф, 2008. 272 с

3. Wilson W.W., Dahl B.L. Logistical Strategies and Risks in Canadian Grain Marketing // Canadian Journal of Agricultural Economics. 2000, 48, P. 141-160. doi: 10.1111/j.1744-7976.2000.tb00271.x

4. Krueger A., Dooley F., Berruto R., Maier, D. Risk Management Strategies for Grain Elevators Handling Identity-Preserved Grains // IAMA World Food and Agribusiness Congress West Lafayette. 2000. IN. June.

5. Lobo D.S., Conte H. Comparison of logistics strategies of two cooperatives in the poultry sector using Stated Preference Technique / POMS 23rd Annual Conference. Chicago, Illinois, U.S.A. 2011. April 20 to April 23

6. Manikas I., Kelemis A., Folinas D. Modeling of logistics processes in the Agrifood Supply Chain CIOSTA \& CIGR Section // V Conference 201129 June - 1 July 2011, Vienna, Austria. URL: http://www.nas.boku.ac.at/fileadmin/_H93/H931/CIOSTA_Presentations/man ikas.pdf (дата звернення: 2.11.2021)

7. Schlecht Sh. M., Wilson W.W., Dahl B.L. Logistical Costs and Strategies for Wheat Segregation. Agribusiness \& Applied Economics Report. 2004. № 551, 34 p.

8. Тюріна Н.М., Гой І.В., Бабій І.В. Логістика: навч. посіб. К.: «Центр учбової літератури», 2015.392 с.

9. Ніколюк О.В., Донець Л.Я Інноваційні засади управління системою логістичних бізнес-процесів зер- 
нового господарства // Економіка харчової промисловості. $2020 . \quad$ Т.12, $\quad$ вип. $2 . \quad$ С. $68-75$. doi:10.15673/fie.v12i2.1742

10. Крикавський Є.В. Логістика. Для економістів: підручник. Львів: Видавництво Національного університету «Львівська політехніка», 2004. 448 с.

Стаття надійшла 9.11.2021

Стаття прийнята до друку 23.11.2021

Доступно в мережі Internet 30.12.21

Nikoliuk 0.

Doctor of Economics, Professor

Department of Public Administration

Email: alenavn11@gmail.com

ORCID ID: 0000-0002-1665-0361

\section{Sokoliuk K.}

Ph.D., Associate Professor

Department of Marketing, Business and Trade

E-mail:katya.sokoluk@meta.ua

ORCID ID: 0000-0002-0758-6468

\section{Dymbovskaya L.}

Undergraduate

Department of Management and Logistics

Odessa National Academy of Food Technologies

Kanatna str., 112 Odesa, Ukraine, 65039

E-mail: Id270399@gmail.com

ORCID ID: 0000-0003-3809-4973

\section{LOGISTICS OF FUNCTIONAL AREAS: THEORETICAL APPROACHES}

The article formulates universal theoretical and methodological principles of the logistic approach, which is used to solve various problems of strategic management of enterprises. The principles of the theory of personnel logistics have been offered, first of all conceptual and scientific-methodical provisions on maintenance of the organization and increase of efficiency of use of the personnel of the enterprises on the corresponding methodological bases of implementation of the logistic approach. Manifestation of the ideology of the logistics approach, which is universal in nature and aimed at strengthening the cross-functional coordination of structural units of enterprises is presented by four interrelated trends: the integration of local functions of the enterprise into integrated functions, ie business processes; reduction of the total number of functions; structuring of organizations based on integrated functions; optimization of business processes in general. It has been determined that the logistics approach is an important component in ensuring the adaptability of enterprises to the external environment. It has been established that the formation of logistics systems in commerce involves the integration of systems of movement of goods and material flows on the basis of coordination of all processes of promotion, from procurement to delivery to consumers, integration of goods flow management, unified material flow technology, together with services provided for the clients of a trade enterprise, adaptation of logistics systems to changes in the external and internal environment of commercial logistics, rational organization of all elements of commercial logistics, ensuring their compatibility in organizational and technological terms, and more. mechanisms.

Key words: logistics, management; enterprises, personnel, management system, logistics,

\section{References}

1. Drobotia, Ya. A. (2011). Upravlinnia lohistykoiu materialnykh zapasiv ahrarnykh pidpryiemstv (dissertation... kand. ekon. nauk: 08.00.04: zakhyst: 30 veresnia 2011 r., Kerivnyk: Perebyinis V. I.). Poltavska derzhavna ahrarna akademiia, Poltava. doi: 10.1055/s-0038-1628407

2. Savenko, I. I. (2008). Lohistychnyi pidkhid v upravlinni potokamy zernozberihaiuchykh pidpryiemstv. Teoretyko-pravovyi ta metodolohichnyi aspekty. Polihraf.

3. Wilson, W. W., \& Dahl, B. L. (2000). Logistical Strategies and Risks in Canadian Grain Marketing. Canadian Journal of Agricultural Economics, (48), 141-160. doi: 10.1111/j.1744-7976.2000.tb00271.x

4. Krueger, A., Dooley, F., Berruto, R., \& Maier, D. (2000). Risk Management Strategies for Grain Elevators Handling Identity-Preserved Grains. IAMA World Food and Agribusiness Congress West Lafayette.

5. Lobo, D. S., \& Conte, H. (2011). Comparison of logistics strategies of two cooperatives in the poultry sector using Stated Preference Technique. In POMS 23rd Annual Conference. (April 20 to April 23, 2011). Chicago, Illinois. 
6. Manikas, I., Kelemis, A., \& Folinas, D. (2011). Modeling of logistics processes in the Agrifood Supply Chain CIOSTA \& CIGR Section. In V Conference. (29 June - 1 July, 2011). Vienna. Retrieved November 02, 2021, from http://www.nas.boku.ac.at/fileadmin/_/H93/H931/CIOSTA_Presentations/man ikas.pdf

7. Schlecht, Sh. M., Wilson, W. W., \& Dahl, B. L. (2004). (rep.). Logistical Costs and Strategies for Wheat Segregation. Agribusiness \& Applied Economics Report, № 551, (pp. 1-34).

8. Tiurina, N. M., Hoi, I. V., \& Babii, I.V. (2015). Lohistyka. Tsentr uchbovoi literatury».

9. Nikoliuk, O. V., \& Donets, L.Ya (2020). Innovatsiini zasady upravlinnia systemoiu lohistychnykh biznesprotsesiv zernovoho hospodarstva. Ekonomika kharchovoi promyslovosti, 12(2), 68-75. doi:10.15673/fie.v12i2.1742

10. Krykavskyi, Ye. V. (2004). Lohistyka. Dlia ekonomistiv. Vydavnytstvo Natsionalnoho universytetu «Lvivska politekhnika».

Received 9 November 2021 Approved 23 November 2021 Available in Internet 30.12.21

Цитування згідно ДСТУ 8302:2015

Ніколюк О.В., Соколюк К.Ю., Димбовська Л.І. Логістика функціональних областей: теоретичні підходи // Економіка харчової промисловості. 2021. Т.13, вип. 4. С.34-40. doi 10.15673/fie.v13i4.2191

Cite as APA style citation

Nikoliuk, O., Sokoliuk, K., \& Dymbovskaya, L. (2021). Logistics of functional areas: theoretical approaches. Food Industry Economics, 13(4), 34-40. doi 10.15673/fie.v13i4.2191 